\title{
THE EFFECTS OF ETHANOLIC EXTRACT OF ROOT OF SPHENOCENTRUM JOLLYANUM PIERRE ON SEXUAL BEHAVIOUR AND HORMONAL LEVELS IN RODENTS
}

\author{
W. K.B.A. Owiredu' ${ }^{1}$ A. Nafiu ${ }^{1}$; F. Amissah ${ }^{2}$; E. Woode ${ }^{2}$ \\ ${ }^{1}$ Department of Molecular Medicine, School of Medical Sciences, \\ College of Health Sciences, Kwame Nkrumah University of Science and Technology, Kumasi, Ghana \\ ${ }^{2}$ Department of Pharmacology, Faculty of Pharmacy and Pharmaceutical Sciences, \\ College of Health Sciences Kwame Nkrumah University of Science and Technology, Kumasi, Ghana.
}

\begin{abstract}
Roots of S. jollyanum are considered as sexual stimulant in Ghanaian traditional medicine. The present study is aimed at investigating the effect of an ethanolic extract of the root of $S$. jollyanum on sexual behaviour of male mice and reproductive hormones in male rats. Extract of $S$. jollyanum (100, 300 and $1000 \mathrm{mg} / \mathrm{kg} \mathrm{p.o)}$ stimulated mounting and mating behaviour by increasing mounting frequency, intromission frequency and prolonged ejaculation latency. In addition, a decrease in mounting latency, intromission latency and postejaculatory interval was observed. These observations were indicative of increased libido and enhanced sexual behaviour. However, the dose-response curves of some of the parameters measured (attempted mounts, mounting frequency, anogenital sniffing and penile licking) were U-shaped i.e. the effects observed were absent at higher doses. Also the effect of the extract on FSH, LH, prolactin and testosterone levels in rats were determined at weekly intervals for three weeks. Levels of testosterone were increased 4-fold by the third week and there was about $30 \%$ increase in FSH levels by the second week which dropped by the third week. Surprisingly, LH levels were reduced by the second week with no significant change in levels of prolactin. These results suggest that there may be more than one mechanism of action of the extract. The immediate increase in sexual behaviour by extract of $S$. jollyanum may be due to a central stimulatory effect whilst long-term effect might be due to increased testosterone levels. The stimulation of sexual behaviour in male mice and rats supports the claims for its traditional usage in sexual disorders.
\end{abstract}

Keywords: Sphenocentrum jollyanum, erectile dysfunction, sex hormones, rat, mice

\section{INTRODUCTION}

Erectile dysfunction is considered as one of the most important public health problems, since it affects a high percentage of men. Though there are several orthodox medicines available (e.g. sildenafil which competitively inhibits type-5 cGMP-specific phosphodiesterase enzyme and therefore causes vasodilatation in cavernous muscles leading to erection, alprostadil $\left(\mathrm{PGE}_{1}\right)$ which acts by inhibiting noradrenalin (NA) release and increases intracellular cAMP in the corpus cavernosum smooth muscle cells through EP receptor stimulation (Traish et al.,1997), amphetamine, caffeine, and apomorphine which 
increase sexual behavior non-specifically through CNS simulation), herbal remedies continue to provide a popular alternative for men seeking to improve their sexual life (Aversa and Fabbri, 2001; Tharakan et al., 2006). In erectile dysfunction (ED), the balance between contractant and relaxant factors is controlled by central and peripheral mechanisms, and involves many transmitters and transmitter systems, a lot of drugs with diverse mechanisms of action are used in the management of erectile dysfunction.

Several plants are used for their reputed aphrodisiac properties worldwide. In Ghana, plants such as Pausinystalia yohimbe, Landolphia dulcis, Capparis erythrocarpus, Euadenia eminens (usually sold with tiger nuts, Cyperus esculentus), Turrea heterophylla, Corynanthe pachycerus, Piper guineense, and Sphenocentrum jollyannum are used to enhance libido and sexual function (Abbiw, 1990; Mshana et al., 2000).

Sphenocentrum jollyanum Pierre belongs to the family Menispermaceae and in Ghana, it is known in Akan as aduro kokoo (red medicine) or okramankote (dog's penis). It is a small erect sparsely branched shrub, growing up to $1.5 \mathrm{~m}$ in height. The roots which are bright yellow with a sour taste (Neuwinger, 1996) are used as 'chewsticks', relief for constipation, as a stomachic, as a cough medicine, for sickle cell disease, rheumatism and other inflammatory conditions (Burkill, 1985; Iwu, 1993; Moody et al., 2006). The root of $S$. jollyanum is chewed as a central nervous system (CNS) stimulant and aphrodisiac in Ghana (Abbiw, 1990; Irvine, 1961).

Some scientific work has been done on this plant in relation to its antiviral and anti-inflammatory activities (Moody et al., 2002a; Moody et al., 2002b; Moody et al., 2006), anti-oxidant and anti-angiogenic property (Nia et al., 2004) and recently, Raji et al., (2006), have shown that methanolic extract of root of $S$. jollyanum increased the testosterone levels in albino rats as well as a dose-dependent reduction in progressive motility of spermatozoa, viability and total sperm count.
The present study seeks to (i) investigate the sexual behavioural effect of an ethanolic extract of root of $S$. jollyanum in murine models and (ii) further determine the effect of the ethanolic extract on serum levels of other reproductive hormones in male rats with the aim of validating the folkloric use of the plant.

\section{MATERIALS AND METHODS \\ Plant material}

The sun-dried roots of the Sphenocentrum jollyanum Pierre (family Menispermaceae) were bought from the Central Market, Kumasi and identified by Dr. T.C. Fleischer, Department of Pharmacognosy, KNUST, Kumasi, Ghana and a voucher sample was deposited at the Department.

\section{Preparation of the root extract}

The roots were pulverized with a hammer-mill to obtain a coarse powder and $5 \mathrm{~kg}$ of the powder was extracted with $70 \%(\mathrm{v} / \mathrm{v})$ ethanol in a Soxhlet apparatus for $24 \mathrm{~h}$. Using a vacuum rotary evaporator, the hydro-alcoholic filtrate was concentrated under reduced pressure to obtain a yellowish-brown syrupy mass which was then airdried at room temperature $\left(28^{\circ} \mathrm{C}\right)$ for 36 hours. This yielded $478 \mathrm{~g}(9.56 \%)$ extract which was kept in a dessicator at room temperature and is subsequently referred to as extract or SJE.

\section{Animals}

Male ICR mice (25-35 g; 2-3 months old) and Sprague-Dawley rats (250-300 g; 3 months old) were purchased from Noguchi Memorial Institute for Medical Research, University of Ghana, Accra and housed at the animal facility of the Department of Pharmacology, KNUST, Kumasi, Ghana. The animals were housed in groups of 6 in stainless steel cages $(34 \times 47 \times 18 \mathrm{~cm})$ with soft wood shavings as bedding, fed with normal commercial pellet diet (GAFCO, Tema), given water ad libitum and maintained under laboratory conditions. All sexual behavioural experiments were carried out under dim light and therefore, to ac-

10 Journal of Science and Technology, Volume 27 no. 2, August, 2007 
climatize the animals to the test conditions, they were brought to the laboratory and exposed to dim light at the stipulated time of testing daily for 6 days before the experiment. All animals used in these studies were treated in accordance with the National Institute of Health Guidelines for the Care and Use of Laboratory Animals (NIH, Department of Health and Human Services publication no. 85-23, revised 1985) and the study was approved by the Faculty Ethics Committee.

\section{Drugs and Chemicals}

Progesterone (Krka Pharmaceutical, Slovenia), oestradiol benzoate (Phyto-Riker Pharmaceuticals, Accra, Ghana), NoviWell ${ }^{\mathrm{TM}}$ testosterone, follicle-stimulating hormone (FSH), prolactin (PRL) and luteinizing hormone (LH) assay kits (HySkill Diagnostics, Bahlingen, Germany).

\section{Sexual Behaviour Studies on Male Mice}

Reproductive behaviors are critical for the evolutionary success of an individual, and the expression of these behaviors as well as the neural and hormonal mechanisms underlying them have been the focus of study in many laboratories. Male reproductive behavior occurs as a sequence of complex motor behaviors. In the rodent the sequence typically starts with anogenital investigation of the stimulus female, followed by mounts and intromissions, and culminates in ejaculation. To identify drugs that reliably function as aphrodisiacs, various methodological indices have been employed. However, the criteria used to establish the aphrodisiac nature of a compound remain elusive. Three main components of male sexual behavior (Hollister, 1982) and their equivalent terms used for man (Clark et al., 1984) have been proposed, i.e., (i) arousal (libido in man); (ii) erectile and ejaculatory responses (potency in man) and (iii) increased sexual pleasure.

\section{Mounting behaviour}

To quantify mounting behaviour, experiments were designed as described by Lawler (1984) to measure the libido of the male mice (Taha et al., 1995; Tajuddin et al., 2005). Mount is operationally defined as the male assuming the copulatory position but failing to intromit and an attempted mount defined as incompetent mounts in which the orientation is wrong, such as mounts of the female's head or side. Male mice were dosed with saline (control group) or with SJE root extract (100-1000 mg/kg; p.o.) and placed individually in a plexiglas cage $\left(60^{\prime} 75^{\prime} 20 \mathrm{~cm}\right)$. After 15 minutes of acclimatization, a non-oestrous female was introduced into the arena and the number of mounts recorded during a 15-minutes observation period. Then the female was separated for 105 minutes and re-introduced and the number of mounts was observed again for 15 minutes as before. The first observation period was designated as the $1^{\text {st }}$ hour and the second, the $3^{\text {rd }}$ hour. All the experiments were performed between 09.00 to $12.00 \mathrm{hrs}$ at room temperature $26-27^{\circ} \mathrm{C}$.

\section{Mating behaviour}

The effect of the extract on mating behaviour was carried out by a modification of methods described by (Dewsbury and Davis, 1970; Szechtman et al., 1981). This experiment measures the enhancement of sexual performance by the extract (Taha et al., 1995; Tajuddin et al., 2005). Healthy and sexually-experienced male mice were selected for the study. Animals were divided into four groups each consisting of six mice and placed individually in separate plexiglas cages during the experiment. A baseline sexual behaviour study was carried out in mice from all groups to render them sexually experienced. Group 1 served as control group and received $10 \mathrm{ml} / \mathrm{kg}$ of saline orally. Groups 2-4 received suspension of the extract orally at the doses of 100,300 and $1000 \mathrm{mg} / \mathrm{kg}$, respectively, 30 minutes before the start of the experiment. Female mice were brought to oestrus by sequential administration of oestradiol benzoate (10 $\mu \mathrm{g} / 100 \mathrm{~g}$ body weight) and progesterone (500 $\mu \mathrm{g} / 100 \mathrm{~g}$ body weight), through subcutaneous injections, 48 hours and 4 hours before the copu- 
latory studies respectively (Srilatha et al., 1999). All drugs were suspended in the vehicle (normal saline)

Sexual behaviour studies were carried out in a room under dim red illumination as described by (Dewsbury et al., 1972). The male mice were placed individually in a rectangular plexiglas chamber, 10 minutes before the introduction of a primed female, for it to get acclimatized to the chamber conditions. A primed female was then paired with a male and the following sexual behaviour parameters were recorded:

a) mount frequency (MF): the number of mounts without intromission from the time of introduction of the female until ejaculation,

b) intromission frequency (IF): the number of intromissions from the time of introduction of the female until ejaculation,

c) mount latency (ML): the time interval between the introduction of the female and the first mount by the male,

d) intromission latency (IL): the interval from the time of introduction of the female to the first intromission by the male (characterized by pelvic thrusting and springing dismount),

e) ejaculation latency (EL): the time interval between the first intromission and ejaculation (characterized by longer, deeper pelvic thrusting and slow dismount followed by a period of inactivity),

f) post-ejaculatory interval (PEI): the time interval between ejaculation and the first intromission of the following series.

The experiment was terminated when a period of inactivity (which normally results following ejaculation) is observed after a mount and intromission.

\section{Hormonal assays}

\section{Treatment and blood sample collection}

To measure the effect of the extract on testosterone, FSH, LH and prolactin levels, several blood samples were collected at weekly intervals for three weeks during the study: in vehicle-treated or SJE-treated (100-1000 mg/kg, p.o.) animals. Blood was collected into Vacutainer ${ }^{B}$ tubes from the jugular veins of animals killed by a sharp blow on the head. The blood was centrifuged at $500 \mathrm{~g}$ for $15 \mathrm{~min}$ and serum was collected and stored at $-20{ }^{\circ} \mathrm{C}$ until assayed. Male rats were placed in four groups of 18 animals each. Group $A$, the vehicle-treated control, received $10 \mathrm{ml} / \mathrm{kg}$ of saline daily via an intra-gastric syringe. Groups B, $C$ and $D$ were dosed with SJE at 100 , 300 and $1000 \mathrm{mg} / \mathrm{kg}$ (p.o.) respectively daily. At the end of each week, rats (6 per group) were sacrificed and blood samples collected for the assays

\section{Sandwich enzyme immunoassay (SIA) for prolactin, $\mathrm{LH}, \mathrm{FSH}$ and testosterone}

Serum testosterone, follicle-stimulating hormone (FSH), prolactin (PRL) and luteinizing hormone (LH) were determined by sandwich enzyme immunoassay (SIA) using NoviWell ${ }^{\mathrm{TM}}$ assay kits (HySkill Diagnostics, Bahlingen, Germany). Assays were carried out as described by the manufacturer. The assay is based on simultaneous binding of hormone to two monoclonal antibodies; one is immobilized on the microplate, the other is soluble and conjugated with horseradish peroxidase (HRP). Briefly, $2 \mu$ l aliquots of standards and samples were dispensed into their respective wells in ready-to-use microtitre plates precoated with anti-hormone IgG antibodies. After the addition of $100 \mu$ anti-hormone HRP conjugate (1:100 dilution) to each well, the plates were incubated for $30 \mathrm{~min}$ at room temperature. The contents of the well were then aspirated and the wells washed twice with $200 \mu$ l of distilled water. The enzyme reaction was started by addition of the chromogen (tetramethylbenzidine/ hydrogen peroxide system) into each well. Plates were then incubated for $10 \mathrm{~min}$. The reaction was stopped by addition of $100 \mu \mathrm{l}$ of $0.15 \mathrm{M}$ $\mathrm{H}_{2} \mathrm{SO}_{4}$. Absorbance was measured at $450 \mathrm{~nm}$ in an ELx800 ${ }^{\mathrm{TM}}$ Microplate Reader (Bio-Tek In-

12 Journal of Science and Technology, Volume 27 no. 2, August, 2007 
strument, Winooski, VT, USA). Within-assay coefficient of variation was 6.1 for PRL, $6.1 \%$ for $\mathrm{FSH}, 5.4 \%$ for $\mathrm{LH}$, and $6.2 \%$ for testosterone. The analytic sensitivities of the assays were 1.0 $\mathrm{mIU} / \mathrm{ml}$ for $\mathrm{FSH}$ and $\mathrm{LH}$ and $1.0 \mathrm{ng} / \mathrm{ml}$ and 0.1 $\mathrm{ng} / \mathrm{ml}$ for PRL and testosterone as provided by the manufacturer.

\section{Statistical Analysis}

All data are presented as mean $( \pm$ SEM). Data were analysed using two-way repeated measures analysis of variance (ANOVA) with two between-subject factors (time drug treatment) followed by Bonferroni's test. To further compare differences between groups, one-way ANOVA was performed with Tukey's test for selected pairs as post hoc. In all statistical tests, a value of $P<0.05$ was considered significant.

\section{RESULTS AND DISCUSSION}

Roots of $S$. jollyanum are chewed in Ghana as a stimulant and aphrodisiac (Irvine, 1961; Abbiw, 1990). This study aims at investigating the sexual behavioural effects of an extract of the plant in male mice as a means of validating the folkloric use. Also, levels of reproductive hormones have been measured in an attempt to elucidate a possible mechanism of the extract. Mice were used for the behavioural experiments since they share many features at the anatomical, cellular, biochemical, and molecular level with human as well as sharing with human brain functions, such as anxiety, hunger, circadian rhythm, aggression, memory, sexual behaviour and other emotional responses (Van Meer and Raber, 2005)

Male sexual behaviours in mounting test: In these series of experiments, the males were paired with non-oestrus females. Non-oestrus females are usually non-receptive and thus the number of mounts and attempted mounts are direct effects of the extract on libido. Figure 1 shows the acute effect of the extract on sexual behaviours in male mice. Compared with vehicle-treated males, SJE decreased significantly the latency to mount by 37.31 and $41.28 \%$ at 100 $\mathrm{mg} \mathrm{kg}^{-1}$ and by 58.2 and $16.23 \%$ at $300 \mathrm{mg} \mathrm{kg}^{-1}$ one hour and three hours after treatment respectively (Fig. 1a). Two-way ANOVA revealed that time had no effect on the latency $\left(F_{1,40}=0.57\right.$; $P=0.46$ ).
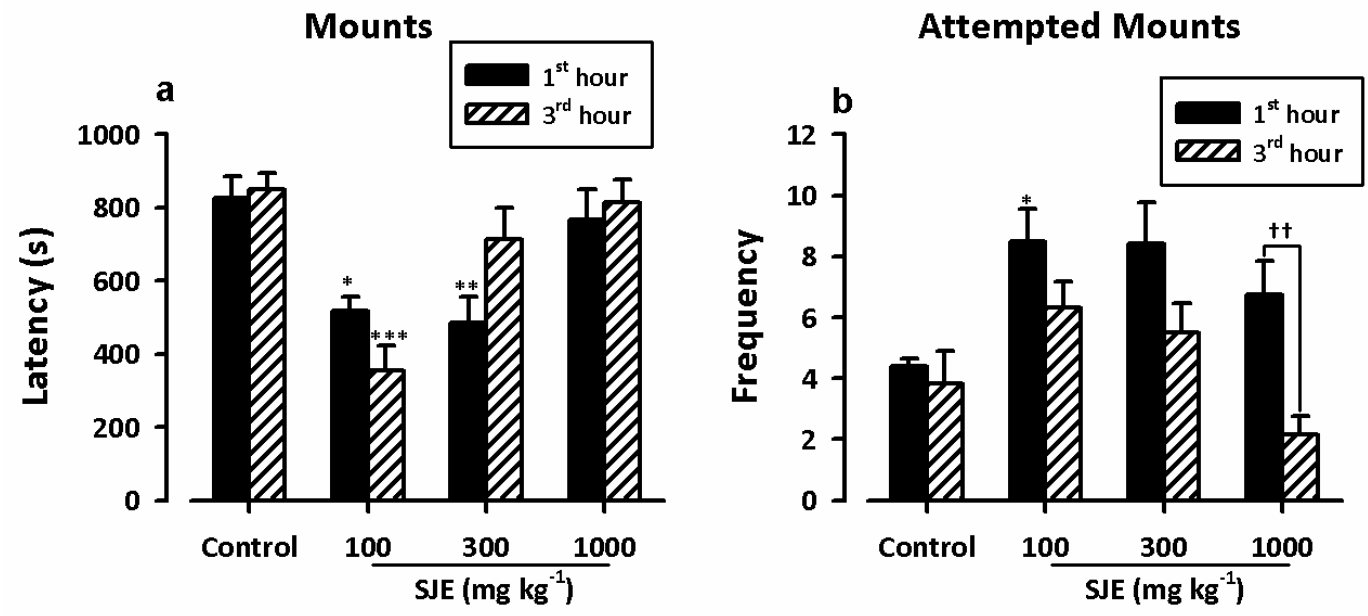

Journal of Science and Technology, Volume 27 no. 2, August, 2007 

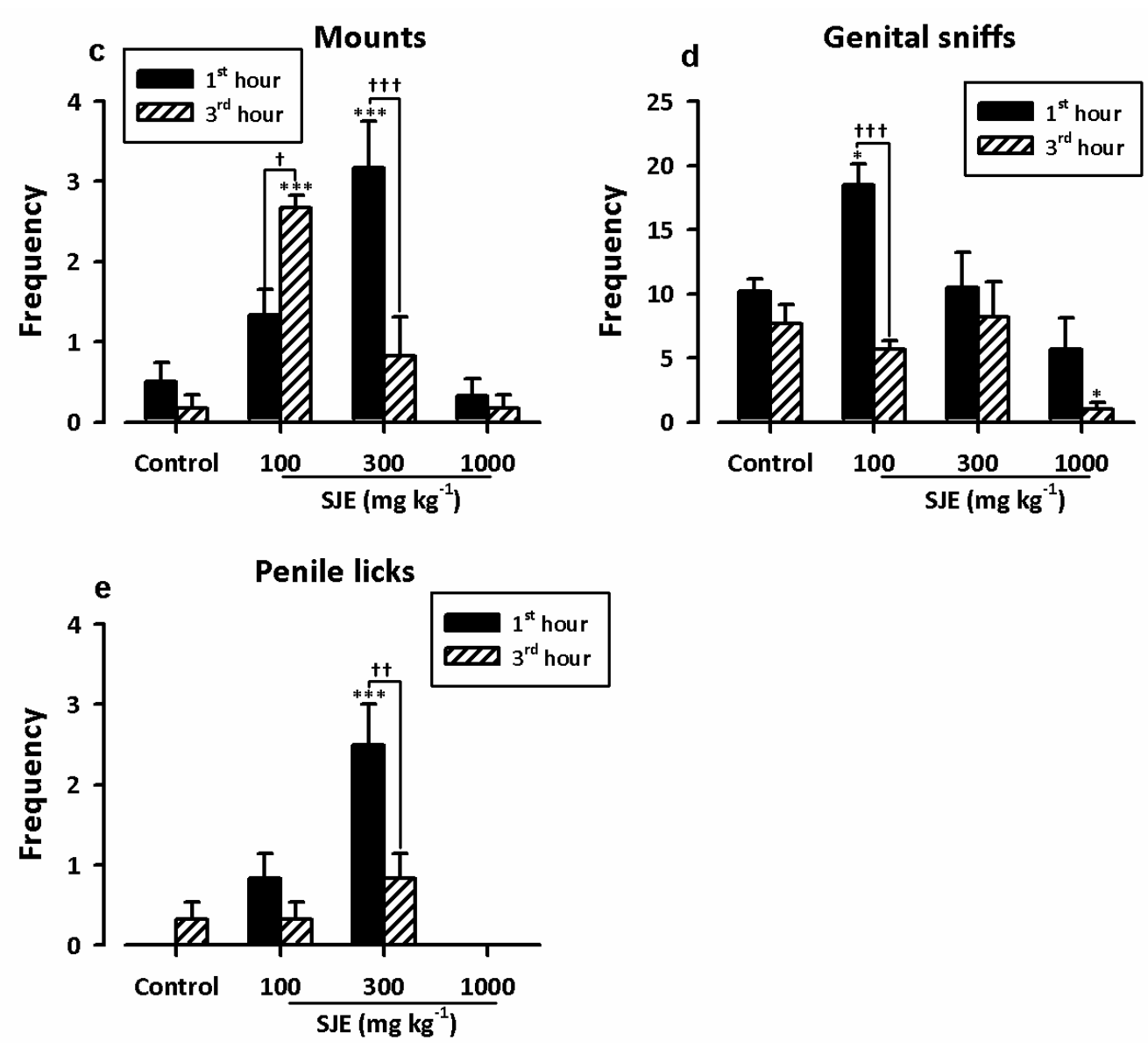

Figure 1 Effect of $S J E$ on mounting behaviour in male mice. Results are presented as means \pm SEM. $* P \leq \mathbf{0 . 0 5}, * * P \leq \mathbf{0 . 0 1}, * * * P \leq \mathbf{0 . 0 0 1}$ compared to respective controls (one-way ANOVA followed by Newman-Keuls post hoc); ${ }^{\dagger} P \leq \mathbf{0 . 0 5},{ }^{\dagger \dagger} P \leq \mathbf{0 . 0 1},{ }^{\dagger \dagger} P \leq \mathbf{0 . 0 0 1}$ (two-way repeated measures ANOVA followed by Bonferroni's post hoc).

The frequency of each behavioural parameter after SJE treatment produced a bell-shaped doseeffect curve. Only the $100 \mathrm{mg} \mathrm{kg}^{-1} \mathrm{SJE}$ significantly increased the frequency of attempted mounting and genital sniffing in the $1^{\text {st }}$ hour $(P<0.05$ for both parameters). In contrast, the $300 \mathrm{mg} \mathrm{kg}^{-1}$ treatment produced frequency of higher mounts and penile licking than the lower dose. Increases in anogenital sniffing and penile licking are indicative of arousal (Taha et al., 1995). Reasons for the U-shaped dose-response curves are not very clear. However, roots of $S$. jollyanum have been shown to have a stimulant property in murine behavioural model (Woode et al., 2006). Psychostimulants would normally show anxiogenic property in a murine models of anxiety (Pellow et al., 1985; Lister, 1987; Lapin, 1993; Varty et al., 2002). Anxiety has been

14 Journal of Science and Technology, Volume 27 no. 2, August, 2007 
shown to decrease sexual behaviour in rodents (Bale et al., 2001; Brien et al., 2002; Barrot et al., 2005). Though stimulants may be useful in erectile dysfunction, they are only effective when the dysfunction is psychogenic. That is when there is hypoactive sexual desire in which case anxiety may lead to excitement inhibition (Kandeel et al., 2001). Apomorphine, a dopamine agonist, stimulates copulatory behaviours in mice and rats also exhibit a hormetic doseresponse curve (Sugiura et al., 1997). Also, the extract supposedly contains several components so at higher doses the inhibitory components may predominate over the stimulatory components. In some instances, the observed effects had worn out by the $3^{\text {rd }}$ hour whilst in others the effect was more pronounced in the $3^{\text {rd }} \mathrm{hr}$. This may be due to interplay of the onset and duration of action which was beyond the scope of this study.

\section{Male sexual behaviours in mating tests:}

In these experiments female were rendered receptive by pre-treatment with an oestrogenprogestogen combination. Figure 2 shows the acute effect of SJE on mounting and intromission. Compared with the vehicle-treated group, SJE (100, 300, $1000 \mathrm{mg} \mathrm{kg}^{-1}$; p.o.) significantly decreased the latency of mounting (12.20\%, $56.26 \%$ and $55.33 \%$ respectively), and intromission $(26.00 \%, 33.99 \%$ and $38.55 \%$ respectively) in a dose-dependent manner. In addition, SJE significantly increased the incidence of mounting (144.43\%, 266.67\% and 300\% respectively) and intromission $(100 \%, 158.84 \%$ and $200.04 \%$ respectively) in a dose-dependent manner. MF and IF are considered as the indices of both libido and potency (Rosen and Ashton, 1993; Ratnasooriya and Dharmasiri, 2000). This is an indication that the test drug possesses a sexual function improving effect. Premature ejaculation is one of the important causes of sexual dysfunction, so the assessment of ejaculatory latency in first series (EL1) and in second series (EL2) was studied (Gauthaman et al., 2002). Latency to ejaculation in both the first series $(10.23 \%, 159.77 \%$ and $60.88 \%)$ and second series $(5.38 \%, 110.33 \%$ and $52.80 \%$ respectively) of mating was also significantly increased (Figure 3). Two-way ANOVA revealed a significant difference inhe ejaculation latency for the $1^{\text {st }}$ and $2^{\text {nd }}$ tseries: the latencies were comparatively greater in the $2^{\text {nd }}$ series $\left(F_{1,40}=27.58 ; P<0.001\right)$. PEI is considered
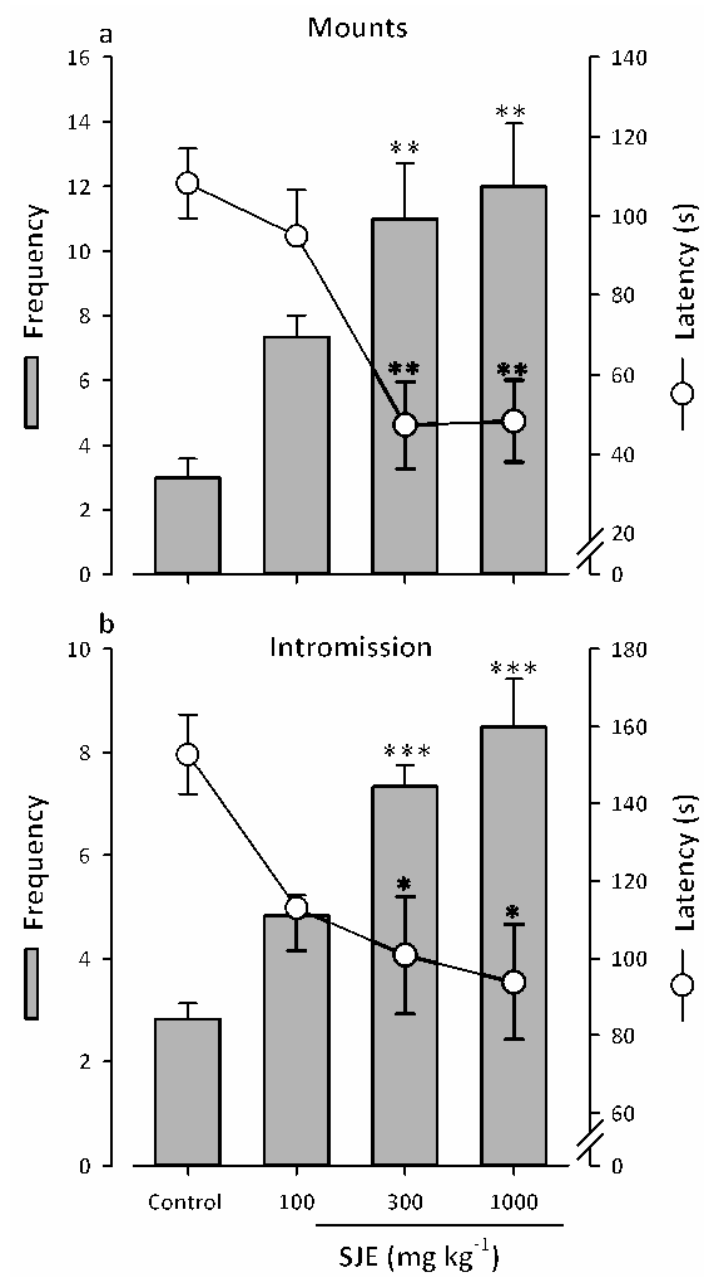

Figure 2: Effects of SJE on the latencies and frequencies to mount (a) and intromit (b) in the mating experiments. Results are presented as means \pm SEM. $* P \leq 0.05, * * P \leq 0.01, * * * P \leq 0.001$ compared to respective controls (one-way ANOVA followed by Newman-Keuls post hoc). 
as an index of potency and libido, and also a parameter of the rate of recovery from exhaustion after first series of mating (Gauthaman et al., 2002). There was a significant decrease in the post-ejaculatory interval by $33.16 \%, 60.36 \%$ and $56.54 \%$ for the 100,300 and $1000 \mathrm{mg} \mathrm{kg}^{-1}$
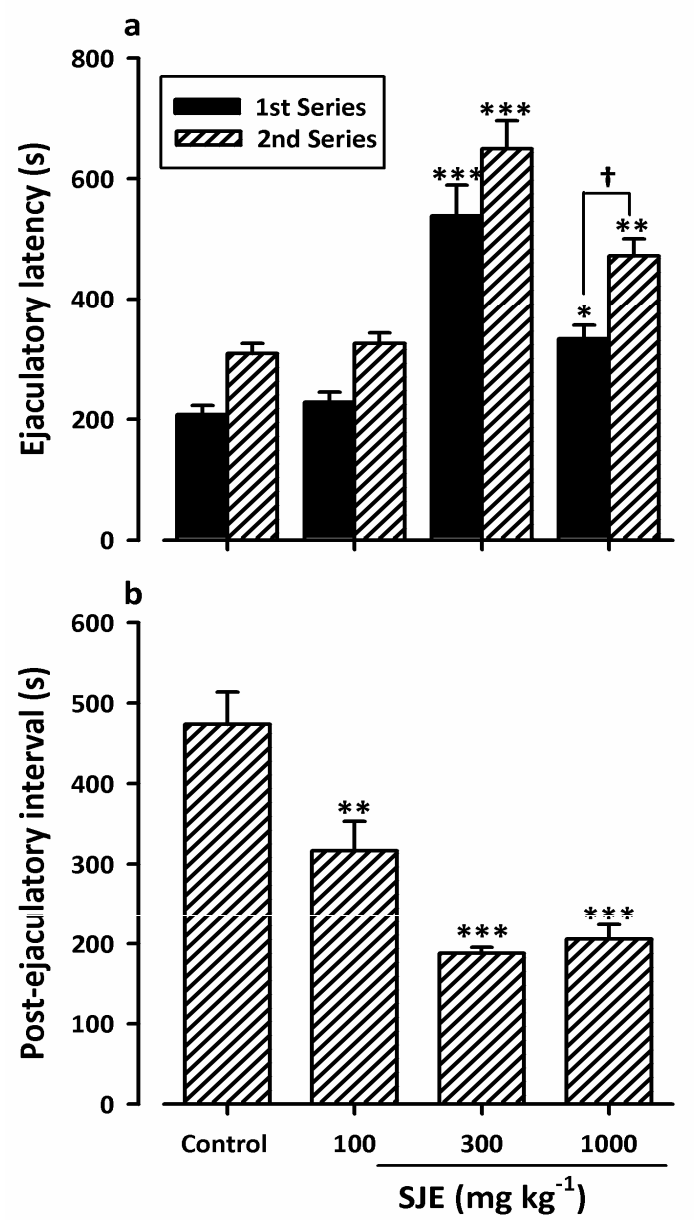

Figure 3 Effects of SJE on ejaculatory latency (a) and post-ejaculatory latencies (b) in male mice. Bars represent means \pm SEM. $* P \leq 0.05$, *** $P \leq$ 0.001 compared to respective controls (one-way ANOVA followed by Newman-Keuls post hoc); ${ }^{\dagger} P \leq 0.05$ (two-way repeated measures ANOVA followed by Bonferroni's post hoc). groups respectively, compared to vehicle-treated groups (Figure 3) Thus, the extract decreased PEI either by enhancing the potency and libido or by producing lesser exhaustion in the first series of mating or both. Apart from the desire that is essential for initiation of sex, penile tumescence and rigidity as well as the accessory muscles that help in providing additional penile rigidity and ejaculation are dependent on testosterone for normal sexual activity (Gauthaman et al., 2002).

Effect of SJE on hormonal levels: SJE treatment had no effect on prolactin levels over the treatment period (Figure 4). However, FSH levels were significantly increased by the $2^{\text {nd }}$ week of treatment in a dose-dependent manner $(\mathrm{p}<$ 0.0001). Though luteinizing hormones were decreased in all the test groups, the level of testosterone was greatly increased by the $3^{\text {rd }}$ week of treatment $(\mathrm{p}<0.0001)$. The increase in testosterone confirms that of Raji et al. (2006) who also reported that a methanolic extract caused a dose dependent significant reduction in progressive motility of spermatozoa, viability and total sperm counts. This finding in which there is increase in testosterone levels without a preceding increase in LH is unusual, because it is well established that testosterone secretion by Leydig cells is mainly under the influence of LH (Catt et al., 1980; Desjardins, 1981; Huhtaniemi et al., 1982). However, some workers have shown that, in vivo, the Leydig cells are programmed to release testosterone not only in response to $\mathrm{LH}$, but also to various local paracrine factors (Huhtaniemi et al., 1982; Klinefelter and Kelce, 1996). Furthermore, studies in the rat have indicated that there is no direct relationship between the trains of LH pulses and the induction of testosterone secretory episodes, with often an active LH secretory period being dissociated from the testicular response (Ellis and Desjardins, 1982; Sodersten et al., 1983; Hakola et al., 1998; Pierroz et al., 1999).

Male sexual behaviour and erection are dependent on testosterone that may act both centrally 

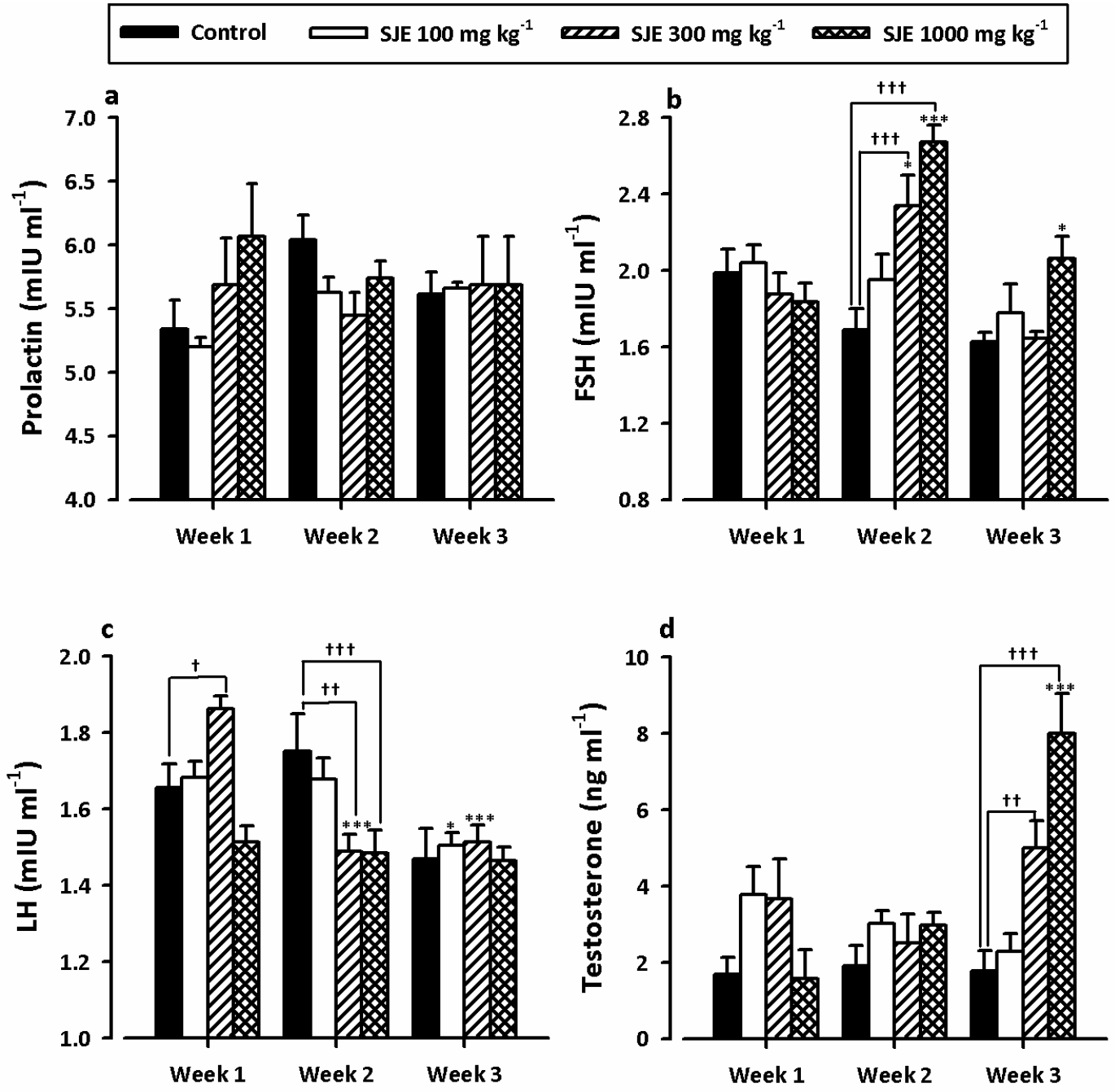

Figure 4 Effect of SJE on reproductive hormones in male Sprague-Dawley male rats. Results are presented as means \pm SEM. $* P \leq 0.05, * * * P \leq 0.001$ compared to respective controls (one-way ANOVA followed by Newman-Keuls post hoc); ${ }^{\dagger} \boldsymbol{P} \leq \mathbf{0 . 0 5}{ }^{\dagger \dagger} \boldsymbol{P} \leq \mathbf{0 . 0 1}{ }^{\dagger \dagger} \boldsymbol{P} \leq \mathbf{0 . 0 0 1}$ (two-way repeated measures ANOVA followed by Bonferroni's post hoc).

and peripherally (Mills et al., 1996). Testosterone supplementation has been shown to improve sexual function and libido (Aversa and Fabbri, 2001) as well as intensifying orgasm and ejaculations (Morales, 1996). Though androgens are known to influence male masculine behaviour, it has been observed that in many animals this behaviour requires weeks, and in some cases longer, to extinguish after castration (Crews, 1983; Meisel and Sachs, 1994), suggesting that some aspects of masculine sexual behaviour can be maintained in a steroid-independent manner. 
It is well established that dopamine (DA) released from the medial preoptic area (MPOA) is essential for activation of adult male sexual behaviour in rats and also mice (Hull et al., 1997; Hull et al., 1999; Cowan, 1992; Kudwa et al., 2005). Furthermore, it is postulated that testosterone may increase DA release by upregulating nitric oxide synthase, which produces nitric oxide, which in turn increases DA release (Hull et al., 1999). As stated earlier, the roots of the plant are chewed as a stimulant in Ghana and we have recently shown in a preliminary report, the anxiogenic properties of SJE in mice in elevated plus maze and open field behavioural models (Woode et al., 2006). This finding supports the possible involvement of central neuronal circuits in the actions of $S$. jollyanum.

\section{CONCLUSION}

The results of this study have provided evidence to support the use of S jollyanum as an aphrodisiac in traditional medicine and that the effect may be due in part to the central stimulatory effect for its acute action whilst the long-term effect due to testosterone.

\section{ACKNOWLEDGEMENTS}

The authors are grateful to Thomas Ansah, George Ofei, Prosper Akortia of the Department of Pharmacology and Prosper Agbodadze of the Deparment of Molecular Medicine for their technical assistance. We are also grateful to the Gates Foundation who partly funded this research

\section{REFERENCES}

Abbiw, D. K. (1990). Useful Plants of Ghana. Intermediate Technology Publications and Royal Botanic Gardens Kew.

Aversa, A. and Fabbri, A. (2001). New oral agents for erectile dysfunction: what is changing in our practice? Asian J Androl 3: 175-9.

Bale, T. L., Davis, A. M., Auger, A. P., Dorsa, D. M. and McCarthy, M. M. (2001). CNS region-specific oxytocin receptor expression: importance in regulation of anxiety and sex behaviour. J Neurosci 21: 2546-52.

Barrot, M., Wallace, D. L., Bolanos, C. A., Graham, D. L., Perrotti, L. I., Neve, R. L., Chambliss, H., Yin, J. C. and Nestler, E. J. (2005). Regulation of anxiety and initiation of sexual behaviour by CREB in the nucleus accumbens. Proc Natl Acad Sci U S A 102: 8357-62.

Brien, S. E., Smallegange, C., Gofton, W. T., Heaton, J. P. and Adams, M. A. (2002). Development of a rat model of sexual performance anxiety: effect of behavioural and pharmacological hyperadrenergic stimulation on APO-induced erections. Int J Impot Res 14: 107-15.

Burkhill HM. 1985. The Useful Plants of West Tropical Africa. Royal Botanic Gardens Kew: London

Catt, K. J., Harwood, J. P., Clayton, R. N., Davies, T. F., Chan, V., Katikineni, M., Nozu, K. and Dufau, M. L. (1980). Regulation of peptide hormone receptors and gonadal steroidogenesis. Recent Prog Horm Res 36: 557662 .

Clark, J.T., Smith, E.R. and Davidson, J.M. (1984) Enhancement of sexual motivation in male rats by yohimbine. Science 225: 847848.

Cowan, A. (1992). Buprenorphine and gastrointestinal transit in rats: effect of naloxone on the biphasic dose-response curve. Clin Exp Pharmacol Physiol 19: 47-9.

Crews D (1983) Control of male sexual behaviour in the Canadian red-sided garter snake. In: Hormones and Behaviour in Higher Vertebrates (Balthazart J, Prove E, Gilles R, eds), pp 398-406. Berlin: Springer

Desjardins, C. (1981). Endocrine signaling and male reproduction. Biol Reprod 24: 1-21.

Dewsbury, D. A. and Davis, H. N., Jr. (1970). Effects of reserpine on the copulatory behaviour of male rats. Physiol Behav 5: 1331-3.

18 Journal of Science and Technology, Volume 27 no. 2, August, 2007 
Dewsbury, D. A., Davis, H. N., Jr. and Jansen, P. E. (1972). Effects of monoamine oxidase inhibitors on the copulatory behaviour of male rats. Bull Menninger Clin 36: 209-17.

Ellis, G. B. and Desjardins, C. (1982). Male rats secrete luteinizing hormone and testosterone episodically. Endocrinology 110: 1618-27.

Gauthaman, K., Adaikan, P. G. and Prasad, R. N. (2002). Aphrodisiac properties of Tribulus Terrestris extract (Protodioscin) in normal and castrated rats. Life Sci 71: 1385-96.

Hakola, K., Haavisto, A. M., Pierroz, D. D., Aebi, A., Rannikko, A., Kirjavainen, T., Aubert, M. L. and Huhtaniemi, I. (1998). Recombinant forms of rat and human luteinizing hormone and follicle-stimulating hormone; comparison of functions in vitro and in vivo. J Endocrinol 158: 441-8.

Hollister, L.E. (1982). Drugs and sexual behavior in man. Life Sci. 17: 661-668

Huhtaniemi, I., Tikkala, L. and Martikainen, H. (1982). Diurnal variation of gonadotrophin receptors in the rat testis. Int J Androl 5: 13744.

Hull, E. M., Du, J., Lorrain, D. S. and Matuszewich, L. (1997). Testosterone, preoptic dopamine, and copulation in male rats. Brain Res Bull 44: 327-33.

Hull, E. M., Lorrain, D. S., Du, J., Matuszewich, L., Lumley, L. A., Putnam, S. K. and Moses, J. (1999). Hormone-neurotransmitter interactions in the control of sexual behaviour. Behav Brain Res 105: 105-16.

Irvine, F. R. (1961). Woody Plants of Ghana. With special reference to the uses. London: Oxford University Press.

Iwu, M.M (1993). Handbook of African Medicinal Plants. CRC Press Inc. p.239.

Kandeel, F. R., Koussa, V. K. and Swerdloff, R. S. (2001). Male sexual function and its disorders: physiology, pathophysiology, clinical investigation, and treatment. Endocr Rev 22: 342-88.
Klinefelter, G., and W. R. Kelce. Leydig cell responsiveness to hormonal and nonhormonal factors in vivo and in vitro. In: The Leydig Cell, edited by A. H. Payne, M. P. Hardy, and L. D. Russell. Cache River Press, 1996, p. 535-553

Kudwa, A. E., Dominguez-Salazar, E., Cabrera, D. M., Sibley, D. R. and Rissman, E. F. (2005). Dopamine D5 receptor modulates male and female sexual behaviour in mice. Psychopharmacology (Berl) 180: 206-14.

Lapin, I. P. (1993). Anxiogenic effect of phenylethylamine and amphetamine in the elevated plus-maze in mice and its attenuation by ethanol. Pharmacol Biochem Behav 44: 241-3.

Lawler, I.J. (1984). Ethnobotany of the Orchidaceace. In: Orchid Biology: Review and Perspectives-3 (Edited by: Arditti J). Ithaca, Cornell University Press, 27-149

Lister, R. G. (1987). The use of a plus-maze to measure anxiety in the mouse. Psychopharmacology (Berl) 92: 180-5.

Meisel RL, Sachs BD (1994). The physiology of male sexual behaviour. In:The Physiology of Reproduction, Vol 2 (Knobil E, Neill JD, eds), pp 3-105. New York: Raven.

Mills, T. M., Reilly, C. M. and Lewis, R. W. (1996). Androgens and penile erection: a review. J Androl 17: 633-8.

Moody JO, Robert VA, Adeniji JA. 2002a. Antiviral effect of selected medicinal plants. I: Diospyros barteri, D. menbutensis and Sphenocentrum jollyanum on polio viruses. Nigerian Journal of Natural products and medicine 6: 4-6.

Moody JO, Robert VA, Hughes JA. 2002b. Antiviral effect of selected medicinal plants. II: Effect of ectracts of Diospyros menbutensis and Sphenocentrum jollyanum on cowpea mosaic viruses. Pharmaceutical Biology 40: 342-345.

Moody, J. O., Robert, V. A., Connolly, J. D. and 
Houghton, P. J. (2006). Anti-inflammatory activities of the methanol extracts and an isolated furanoditerpene constituent of Sphenocentrum jollyanum Pierre (Menispermaceae). Journal of Ethnopharmacology 104: 87-91.

Morales, A. (1996). Androgen supplementation in practice: the treatment of erectile dysfunction associated with hypotestosteronemia. In: Oddens BJ, Vermeulen A, editors. Androgens and aging male. London: Parthenon Publishing Group; pp 233-45.

Mshana, N. R., Abbiw, D. K., Addae-Mensah, I., Adjanohoun, E., Ahyi, M. R. A., Ekpere, J. A., Enow-Orock, E. G., Gbile, Z. O., Noamesi, G. K., Odei, M. A., Odunlami, H., Oteng-Yeboah, A. A., Sarpong, K., Soforowa, A. and Tackie, A. N. (2000). Traditional Medicine and Pharmacopoeia. Contribution to the Revision of Ethnobotanical and Floristic Studies in Ghana. Accra: Organization of African Unity/Scientific, Technical \& Research Commision.

Neuwinger, H.D., 1996. African Ethnobotany: Poisons and Drugs. Chapman and Hall, London, pp.631-632.

Nia, R., Paper, D.H., Essien, E.E., Iyadi, K.C., Bassey, A.I.L., Antai, A.B. and Franz, G. (2004). Evaluation of the Anti-oxidant and Anti-angiogenic Effects of Sphenocentrum jollyanum Pierre. African Journal of Biomedical Research, 7: 129-132.

Pellow, S., Chopin, P., File, S. E. and Briley, M. (1985). Validation of open:closed arm entries in an elevated plus-maze as a measure of anxiety in the rat. $J$ Neurosci Methods 14: 149-67.

Pierroz, D. D., Aebi, A. C., Huhtaniemi, I. T. and Aubert, M. L. (1999). Many LH peaks are needed to physiologically stimulate testosterone secretion: modulation by fasting and NPY. Am J Physiol 276: E603-10.

Raji, Y., Fadare, O. O., Adisa, R. A. and Salami, S. A. (2006). Comprehensive assessment of the effect of Sphenocentrum jollyanum root extract on male reproductive activity in albino rats. Reproductive Medicine and Biology 5: 283-292.

Ratnasooriya, W. D. and Dharmasiri, M. G. (2000). Effects of Terminalia catappa seeds on sexual behaviour and fertility of male rats. Asian J Androl 2: 213-9.

Rosen, R. C. and Ashton, A. K. (1993). Prosexual drugs: empirical status of the "new aphrodisiacs". Arch Sex Behav 22: 521-43.

Sodersten, P., Eneroth, P. and Pettersson, A. (1983). Episodic secretion of luteinizing hormone and androgen in male rats. $J$ Endocrinol 97: 145-53.

Srilatha, B., Adaikan, P. G., Ng, S. C. and Arulkumaran, S. (1999). Elevated lowdensity lipoprotein cholesterol (LDL-C) enhances pro-erectile neurotransmission in the corpus cavernosum. Int J Impot Res 11: 15965.

Sugiura, K., Yoshimura, H. and Yokoyama, M. (1997). An animal model of copulatory disorder induced by social stress in male mice: effects of apomorphine and L-dopa. Psychopharmacology (Berl) 133: 249-55.

Szechtman, H., Hershkowitz, M. and Simantov, R. (1981). Sexual behaviour decreases pain sensitivity and stimulated endogenous opioids in male rats. Eur J Pharmacol 70: 279-85.

Taha, S. A., Islam, M. W. and Ageel, A. M. (1995). Effect of ambrein, a major constituent of ambergris, on masculine sexual behaviour in rats. Arch Int Pharmacodyn Ther 329: 28394.

Tajuddin, Ahmad, S., Latif, A., Qasmi, I. A. and Yusif-Amin, K. M. (2005). An experimental study of sexual function improving effect of Myristica fragrans Houtt. (nutmeg). $B M C$ Complement Altern Med 5: 16.

Tharakan, B., Dhanasekaran, M., Brown-Borg, H. M. and Manyam, B. V. (2006). Trichopus zeylanicus combats fatigue without ampheta-

20 Journal of Science and Technology, Volume 27 no. 2, August, 2007 
mine-mimetic activity. Phytother Res 20: 165-8.

Traish AM, Moreland RB, Gallant C, Huang YH, and Goldstein I (1997) G-proteincoupled receptor agonists augment adenylyl cyclase activity induced by forskolin in human corpus cavernosum smooth muscle cells. Recept Signal Transduct 7:121-132.

Van Meer, P. and Raber, J. (2005). Mouse behavioural analysis in systems biology. Biochem J 389: 593-610.

Varty, G. B., Morgan, C. A., Cohen-Williams, M. E., Coffin, V. L. and Carey, G. J. (2002). The gerbil elevated plus-maze I: behavioural characterization and pharmacological validation. Neuropsychopharmacology 27: 357-70.
Woode, E., Duwiejua, M., Ansah, C., Koffuor, G. A., Obiri, D. D. and Amidu, N. (2006). Effect of Sphenocentrum jollyanum in experimental mouse models of anxiety. In Proceedings of the 2nd Scientific Meeting Western Africa Network of Natural Products Research Scientists (Wannpres). Elmina, Ghana, 32. 